INDEPENDENT JOURNAL OF MANAGEMENT \& PRODUCTION (IJM\&P)

http://www.ijmp.jor.br

v. 11, n. 4, July - August 2020

ISSN: 2236-269X

DOI: 10.14807/ijmp.v11i4.1109

\title{
EFFICIENCY IN EQUIPMENT IMPORT PROCESSES: UNIVASF'S
}

CASE

\author{
Leone Coelho Bagagi \\ Escola de Administração da Universidade Federal da Bahia., Brazil \\ E-mail: leone.bagagi@gmail.com
}

Vera Lúcia Peixoto S. Mendes

Universidade Federal da Bahia, Brazil

E-mail: verapeixoto09@gmail.com

Submission: $8 / 6 / 2019$

Revision: 9/18/2019

Accept: 10/22/2019

\section{ABSTRACT}

This study aims to describe and analyze the administrative flow of equipment import process at UNIVASF considering the principle of administrative efficiency. A qualitative single case study research was carried out, with a survey and analysis of actions, administrative acts developed into equipment import processes, from 2004 to 2014, to foster, and support scientific, technological and innovation research at UNIVASF. The results show that the principle of efficiency, a promise of the new managerialism, does not resonate with the evidences pointed out in this research, due to the higher time spent to perform the phases, especially the fiscal one, due to obstacles in the administrative and legal systems.

Keywords: Efficiency, Equipment Import. Scientific, Technological Research and Innovation. 
DOI: 10.14807/ijmp.v11i4.1109

\section{INTRODUCTION}

The Brazilian state has stimulated and fostered the generation and diffusion of new technologies, aiming to reverse the current scenario of Brazilian technological gap and to project the nation in the scenario of international competitiveness (REZENDE; CORREA; DANIEL, 2013). The inhibited participation of private initiative in this process of national scientific development, combined with the legal requirements in the execution of resources, the transparency of acts and the accountability of results obtained, are structuring factors that transform research actions into an arduous bureaucratic process.

Even with constitutional didactic, administrative and financial autonomy conferred to universities; these institutions are subject to such intricacies that contribute very little to scientific and technological progress. On the contrary, there is the case of importing equipment process to foster scientific research in universities that has become a bureaucratic odyssey. There is a restriction on budgets for research funding, especially basic research, which in Brazil are public funding institutions as the largest funding agent. This is why efficient resource management is a challenge that spurs research in Brazil.

At the heart of this problem are the new federal universities with peculiar characteristics in relation to the older ones: internalization and regionalization of the fulfillment of their institutional mission. UNIVASF is characterized by its performance covering the interior of three federated entities: Bahia, Pernambuco and Piauí. Thus, this phenomenon is seen as a peculiar situation and capable of being the object of scientific analysis aiming to explain this limitation in view of the advances of the new public management, in order to make the process of public procurement efficient in the scope of importation. Thus, it presents itself as a research problem: how is the process of importing equipment at UNIVASF characterized, considering the principle of administrative efficiency?

\section{PUBLIC POLICY TO ENCOURAGE SCIENTIFIC TECHNOLOGICAL RESEARCH IN PUBLIC CONTRACTING}

AND

The legal framework of this public policy was Article 218 of the Brazilian Federal Constitution, which established the guidelines and entrusted the State with the competence to encourage scientific and technological development, by fostering training, financing, support and reducing bureaucracy of public management.

In the context of public procurement, Law n ${ }^{\circ} 8,666 / 93$ (BRAZIL, 1993) precludes some of these actions through the purchase of goods by means of equipment importing process 
DOI: 10.14807/ijmp.v11i4.1109

exclusively for scientific and technological research, financed by funding agencies such as CAPES, FINEP and CNPq, as well as the hiring of a Scientific and Technological Institution (ICT) or by a funding agency, aiming at technology transfer and for the licensing of the right of use or exploitation of protected creation, according to the provisions contained in the article. 24, items XXI and XXV (JUSTEN FILHO, 2009; FURTADO, 2013; DI PIETRO, 2014).

However, even with the establishment of public policies to encourage national scientific research, the process of importing equipment faces exorbitant deadlines to fulfill later stages of procedural instruction and subject to procedural processing in various national public bodies and authorities, namely: import authorization, payment in foreign currency and customs clearance (LIMA, 2014).

The most current legislation in this regard was the approval and sanctioning of the bill called the legal framework of science, technology and innovation, converted into Law $\mathrm{n}^{\circ}$ 13,243 (BRAZIL, 2016), which establishes measures to encourage scientific, technological research and innovation. in the country and, once again, promotes changes in the public procurement system. The laws and ordinary laws issues, the controls exercised by the legislature, besides the principle of transparency and the accountability by the public agents are not able tools to efficiently meet these demands (CARVALHO, 2013; ENSSLIN et al., 2014).

In this sense, it can be highlighted that public procurement, through the process of importing equipment to encourage national research, faces obstacles in its normative and bureaucratic framework, as social and political dynamism is a challenge for administrative systems. and legal entities present in all spheres of public administration.

Thus, it is important to highlight the advances of these policies to promote the development of national scientific and technological research, but caution recommends characterizing this movement as an initial one in order to dismantle the obstacles in the administrative and legal systems. Therefore, the results of these policies are still incipient, considering that such limitations persist and turn research projects management into an odyssey.

\section{EFFICIENCY IN NEW MANAGEMENT AND ITS INSTITUTIONALIZATION IN BRAZILIAN PUBLIC MANAGEMENT}

The term "efficiency" stood out as the most common approach to the new management, according to the references researched. This trend aims to implement actions to maximize 
DOI: 10.14807/ijmp.v11i4.1109

rational use of resources and achievement of results. This tendency was stimulated from the dissonance between social facts and management's performance in relation to norms, which results in a total lack of coherence between public needs and the social end sought by the legislator (CARVALHO, 2013).

Thus, the main objective of the new managerialism in the use of private organizations' mechanisms and procedures to modernize public administration was to make the organization more cost-effective, market-oriented, by building networks and partnerships with for-profit and non-profit institutions. for the provision of public services (MENDES, 2000). This new approach aims to improve quality and increase access and satisfaction of service users, as well as maximize capital resources through efficient management of processes, products, services and, most importantly, financial results (LUKE; KEARINS; VERREYNNE, 2011; MONOBAYEVA; HOWARD, 2015).

In this sense, it can be inferred that the organizational challenge is to promote strategic management efficiently and effectively, always doing more with less (VERMA; SINHA, 2002). Against this background, studies of management science reveal that the movements of managerial public administration, the state apparatus reform movement, and the new managerialism are grounded in the term "effectiveness" and "efficiency," conceptualizing effectiveness as the scope of expected objectives, and efficiency as the development of actions with the least energy expenditure, that is, to develop and achieve the democratic objectives of the state with the least expenditure of public resources (BATISTA JÚNIOR, 2012).

Subsequently, by means of a Constitution amendment, this principle was elevated to the highest normative post in the country, the Federal Constitution of 1988, which considers it as the guiding directive of Brazilian public administration. (BATISTA JÚNIOR, 2012; FURTADO, 2013). The term "efficiency" would be composed by the terms "effectiveness" and "efficiency" of public administration, as well stated by Bandeira de Mello, is the duty of a good administration (MELLO, 2006).

Thus, it can be highlighted that the national normative system institutionalized efficiency as a guiding principle of public administration and, with the prerogative of embracing its conceptual body, aggregated effectiveness through the achievement of results, productivity, economy, quality in the provision of services, agility, maintenance in the continuity of public services and, especially, less bureaucracy of public administration. These 
DOI: 10.14807/ijmp.v11i4.1109

attributes are characterized by state action by maximizing the results in the cost/benefit ratio when providing public services to society.

\section{RESEARCH METHODOLOGY}

This is a qualitative, single-case study (YIN, 2010), conducted at the Vale do São Francisco Federal University Foundation (UNIVASF), a public law body created in 2002 to promote higher education, develop research in several areas of knowledge and promote university extension, inserted in the northeastern semiarid and with multicampus performance. This selection is due to the fact that UNIVASF's strategic position in the development of the northeastern semiarid (including the states of Bahia, Pernambuco and Piauí) and its commitment to scientific and technological progress, whose focus on research and innovation triggered the need for a political-institutional, strategically reshaping the Dean of Research, Graduate and Innovation in the three-dimensional promotion of these actions.

Documentary research was conducted through the survey and analysis according to the actions and administrative acts developed in the equipment importation processes to foster and support scientific, technological and innovation research at UNIVASF. The types of documents were defined by the criterion related to the import processes formalized in the period from 2004 to 2014. The focus is to describe the administrative flow of the equipment import processes of the Budget and Management Dean (PROGEST), considering the principle of administrative efficiency.

The analysis was performed according to the study by Almeida et al (2013) on the "Experience of importing research equipment in ELSA-BRAZIL". This research complies with Resolution n ${ }^{\circ} 466 / 12$ of the National Health Council (BRAZIL, 2012) and was authorized by report of the Ethics and Deontology in Studies and Research Committee $n^{\circ}$ 1,406,593.

\section{RESULTS ANALYSIS}

\subsection{Analysis of Import Processes at UNIVASF}

In this phase, a survey was carried out within UNIVASF's Procurement and Purchase Department of the Budget and Management Dean on all open import processes available for consultation between 2004 and 2014. The flow phases are described below in Table 1, according to the characteristics of procedural instruction and administrative acts specific to the case of UNIVASF, object of this study and, therefore, classified the activities in phases, as presented in the research on equipment import experience for research at ELSA-BRASIL 
DOI: 10.14807/ijmp.v11i4.1109

(ALMEIDA et al., 2013), which are: administrative-operational phase, exchange phase and fiscal phase.

Table 1: Phases and activities for equipment import.

\begin{tabular}{|c|c|}
\hline Phase & Activities \\
\hline \multirow{9}{*}{$\begin{array}{l}\text { Administrative- } \\
\text { operational }\end{array}$} & Technical specification of the equipment. \\
\hline & Contacts with supplier for securities trading, guarantees and technical assistance. \\
\hline & 3. Request and Receipt of Profoma Invoice (Proposal and conditions of acquisition). \\
\hline & $\begin{array}{l}\text { 4. Opening of proceedings, issuance of memoranda and other documents and } \\
\text { authorization by the University Dean. }\end{array}$ \\
\hline & $\begin{array}{l}\text { 5. Documents gathering related to the project (agreement, credit note, work plan, and } \\
\text { others). }\end{array}$ \\
\hline & 6. Statement of the Federal Prosecutor's Office at UNIVASF. \\
\hline & 7. Justification and proof of compatibility with market prices. \\
\hline & $\begin{array}{l}\text { 8. Procurement and Bidding Department registers in the Federal Government } \\
\text { procurement disclosure system for publication in the Federal Official Gazette. }\end{array}$ \\
\hline & $\begin{array}{l}\text { 9. PROGEST issues its commitment in accordance with the dollar quotation and } \\
\text { reinforcement in function of exchange rate variation. }\end{array}$ \\
\hline \multirow[t]{3}{*}{ Foreign exchange } & 10. PROGEST issues bank order to close the exchange rate \\
\hline & $\begin{array}{l}\text { 11. Letter requesting Bank of Brazil to close the exchange rate, related to invoices, in } \\
\text { the form of prepayment. }\end{array}$ \\
\hline & $\begin{array}{l}\text { 12. Issuance and signing of the exchange contract between Bank of Brazil and } \\
\text { UNIVASF. }\end{array}$ \\
\hline \multirow[t]{3}{*}{ Tax control } & $\begin{array}{l}\text { 13. UNIVASF issues letters to the State and Union Treasury bodies requesting granting } \\
\text { exemptions. }\end{array}$ \\
\hline & $\begin{array}{l}\text { 13. Company hired by UNIVASF provides the other acts of clearance with the } \\
\text { IRS, payment and clearance with Brazilian Airport Infrastructure Company } \\
\text { (INFRAERO) and National Health Surveillance Agency (ANVISA), payments for } \\
\text { international and local transportation services, storage and freight services, and other fees } \\
\text { for subsequent reimbursement. }\end{array}$ \\
\hline & 15. Receipt, equipment check and receipt certificate. \\
\hline
\end{tabular}

After analysis of the import processes, nine import processes were identified between the 2004-2014 periods, it could be evidenced that the instruction is carried out by the researcher professor of a large project involving several areas and specialties or by the Coordinator of the Postgraduate studies. The equipment purchased meets the group of research professors involved in the research and graduate programs in multipurpose laboratories.

Ten cases opened under UNIVASF were identified, eight of which registered the beginning of the procedural instruction in the year 2008 and two carried out for the assessment in 2013. It is noteworthy that these procedures are linked to the Graduate Programs and financed by both UNIVASF as well as by development agencies, according to the importation processes studied, Financier of Studies and Projects (FINEP), and Coordination for the Improvement of Higher Education Personnel (CAPES).

The results of the UNIVASF import process survey were described and have the following characteristics: the import processes are analyzed and processed by the team of the 
DOI: 10.14807/ijmp.v11i4.1109

Procurement and Bidding Department (DCL), linked to the Budget and Management Dean (PROGEST), formerly known as Management and Budget Secretariat (SGO).

In the administrative-operational phase, the procedural instruction phase is carried out by the requesting professor/researcher, then PROGEST and DCL analyze it, require the attorney's office manifestation, register it in the Federal Government's procurement disclosure system for publication in the Federal Official Gazette and, lastly, issue the payment commitment. In the foreign exchange phase, PROGEST and DCL provide the issuance of the Official Letter and bank order to close the exchange rate with Bank of Brazil, therefore, the issuance and signing of the exchange contract and prepayment.

In the fiscal phase, it was evidenced that UNIVASF does not have a specialized and sufficient team to provide customs clearance in the import processes for the acquisition of goods. As a result, through process $n^{\circ} 23402.001630 / 2008-30$, the bidding process was carried out in the Electronic Auction $n^{\circ} .84 / 2008$, aiming at hiring a specialized company to develop these activities through reimbursement of expenses and payment of fees for providing these services.

\subsection{Description of the administrative flow of the equipment importing process from UNIVASF's Budget and Management Dean (PROGEST)}

This description characterizes the administrative flow of the equipment import process with the Administrative-operational phase, which highlights the following activities: technical specifications of the equipment; contacts with supplier to negotiate prices, guarantees and technical assistance; request and receipt of proforma invoice (proposal and purchase conditions); opening of proceedings, issuance of memoranda and other documents and authorization from the Dean; the project-related documents (agreement, credit notes, work plan and others); manifestation of the Federal Prosecutor's Office at UNIVASF; Procurement and Bidding Department records in the Federal Government procurement disclosure system for publication in the Federal Official Gazette; PROGEST issues its commitment in accordance with the dollar quotation and possible reinforcement due to exchange variation.

The Exchange phase is related to the following activities: PROGEST issues a bank order to close the exchange rate; issues a letter requesting Bank of Brazil to close the exchange rate in the form of prepayment; issuance and signature of the exchange contract between Bank of Brazil and UNIVASF. 
INDEPENDENT JOURNAL OF MANAGEMENT \& PRODUCTION (IJM\&P)

http://www.ijmp.jor.br

v. 11, n. 4, July - August 2020

ISSN: 2236-269X

DOI: 10.14807/ijmp.v11i4.1109

The Fiscal phase consists of: UNIVASF issuing letters to the State and Union Treasury bodies requesting granting exemptions; the company hired by UNIVASF provides the other acts of clearance with the IRS, as well as payment and clearance with INFRAEROnfraero and ANVISA, discharge of international and local transport services, in addition, storage and freight services, among other things. fee for subsequent disbursement; and, at the end, the receipt, equipment verification and certify receipt of these items.

These phases describe the activities required for the procurement of imported equipment, characterized according to processes carried out at UNIVASF from 2004 to 2014. Ten processes were analyzed, one of which was not concluded and, therefore, was disregarded and nine were the object of this analysis. The processes were coordinated by professors / researchers called Coordinator (A), (B) and (C). In this sense, the time required for the unravel of each phase was analyzed, considering the beginning of the import process with process assessment until the receipt of the equipment in UNIVASF's patrimony sector.

In the administrative-operational phase, as highlighted in Graph 1, it was identified that processes two and three had the longest execution time, respectively, a period of 247 and 234 days. The shortest time was observed in process eight, referring to five days. The average period for compliance with this procedural phase at UNIVASF was 86 days. The exchange phase showed that its longest time was identified in case nine, with a period of 336 days. The shortest time was recorded in case four, with 120 days. The average time of this phase was 180 days. The last phase or tax recorded the longest time to start and complete the activities in process three, with the respective deadline of 392 days. The shortest term was identified in case nine, with a term of 86 days. The average period for the execution of this phase was 190 days.

In this sense, it can be concluded that the import processes in the administrativeoperational phase, in relation to the other phases, present the shortest time for its execution, even considering the longest, shortest and the average time for the development of the activities. Thus, in light of these findings, it can be concluded that even with an average term of almost ninety days to process this first phase, which depends exclusively on the institution's internal actions, the exchange and fiscal phases concentrate the longest period for its conclusion. This means that there is a relationship between these phases and the main limitations identified and categorized, namely: barriers in the legal and administrative system and resources. The Figure 1 illustrates the understanding of this analysis. 


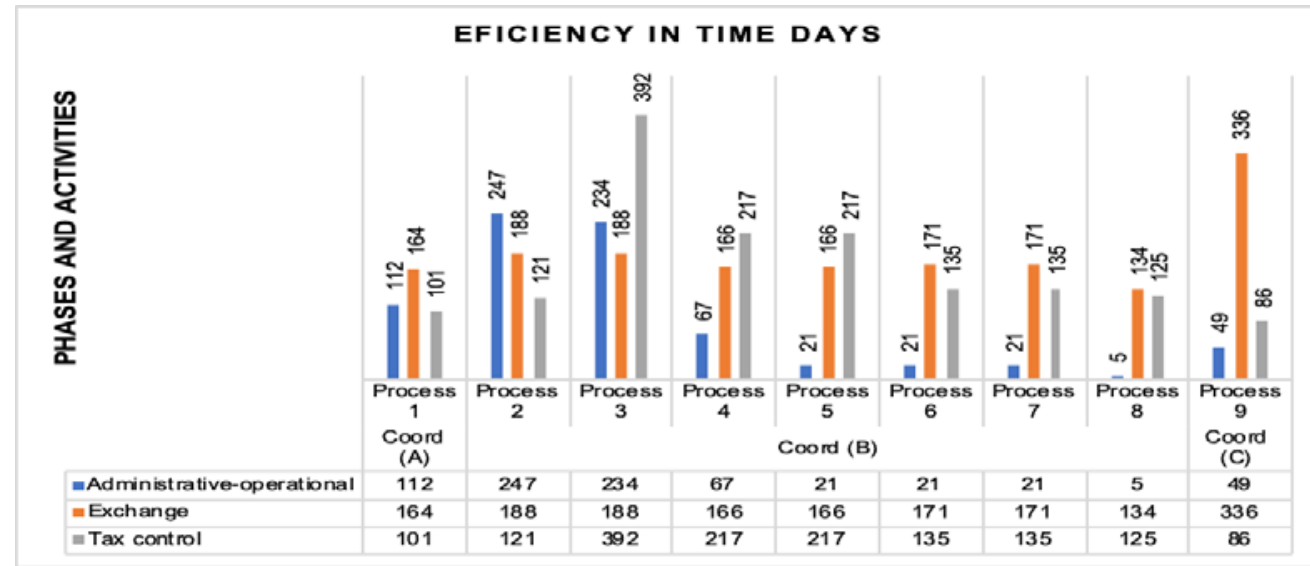

Figure 1: import time per phase and researcher responsible for coordinating the import process. Source: field data.

\section{FINAL CONSIDERATIONS}

The description of the administrative flow of the equipment importation process with UNIVASF's Budget and Management Dean (PROGEST), considering the principle of administrative efficiency, highlights the activities required for public procurement through the import of equipment. In this analysis we found that the shortest period of execution of the activities is in the administrative-operational phase, with the shortest period of five days, there is an average time of 86 days and the largest of 247 days. The foreign exchange phase recorded the shortest period of 120 days, the average time being 180 days and the longest time 336 days. The last phase or tax registers the shortest time - 86 days, the average time of 190 days and the longest time of 392 days.

The administrative flow analysis of equipment import process has a maximum time of 392 days, being the longest fiscal phase and the shortest the administrative-operational phase, reaching up to five days. These deadlines reveal the inefficiency in the importing equipment process for conducting research. These findings highlight that the exchange and fiscal phases have the longest duration in days for their execution. The administrative-operational phase was the shortest, despite the variations in the execution time of its activities.

From the analysis of equipment importation processes in UNIVASF, we observed that the efficiency principle, a promise of the new managerialism approach does not find resonance in the results obtained in this work, being that they are in agreement with the established assumptions. Thus, the results obtained in the research by Almeida et al (2013) are confirmed when they show the varied duration in the administrative-operational phase, but with the shortest duration and the fiscal phase with the longest duration, both found in this study in 
DOI: 10.14807/ijmp.v11i4.1109

Figure 1, as well as the limitations related to the administrative and legal systems and evidenced in research carried out by Almeida et al (2013) and Lima (2014).

From the theoretical perspective, this work seeks to contribute, from the characterization and management of public resources to support and foster scientific, technological and innovation research, to the expansion of the object of this investigation and to analyze whether the principle of efficiency are contributing to suppress barrier challenges in the administrative and legal systems in the equipment importation process.

In practical terms, the results obtained can contribute to subsidize the strategic decisions in the management of these resources and in the import processes. We acknowledge the limitations of this study, especially regarding the non-treatment of the managerial aspect of the studied university, related to the organizational culture and the option for a single case study. Such limitations suggest the proposition of future studies applied in various publicly funded research-supporting organizations, such as private universities, scientific and technological institutions, and private S\&T companies.

\section{REFERENCES}

ALMEIDA, C. P. M. et al. (2013) Experience of importing research equipment at ELSABrazil. Rev. Public Health, São Paulo, v. 47, suppl. 2, jun. Available at: https://repositorio.ufba.br/ri/handle/ri/14257. Accessed on: 05/04/2015

BATISTA JÚNIOR. (2012) The Constitutional principle of administrative efficiency. Belo Horizonte: Forum.

BRAZIL. Constitution (1988) Constitution of the Federative Republic of Brazil. Brasília, DF: Senate, 1988. Official Gazette [of] the Federative Republic of Brazil, Brasília, DF, 05 Oct. 1988. Available at: http://www.planalto.gov.br/ccivil_03/Constituicao/Constituicao.html. Accessed on: 01/02/2019. Accessed on: 01/02/2019.

BRAZIL. Law no 8.666, of June 21, (1993) Regulates art. 37, item XXI, of the Federal Constitution, establishes rules for bids and contracts in the Public Administration and other measures. Official Gazette [of] Federative Republic of Brazil, Brasilia, DF, June 22, 1993, rectified July 6, 1994. Available at: http://www.planalto.gov.br/ccivil_03/leis/L8666cons. htm. Accessed on: 01/02/2019

BRAZIL. Resolution n ${ }^{\circ} 466$ of December 12, (2012) Guidelines and regulatory standards for research involving human beings. Official Gazette [of] Federative Republic of Brazil, Brasilia, DF, 13 June. 2013, Section 1, p. 59. Available at: http://conselho.saude.gov.br/resolucoes/2012/Reso466.pdf. Accessed on: 09/08/2018.

OAK, W. W. (2013) Changes to continuing administrative contracts: a discussion of the determination of the initial value of the contract. 2013. $85 \mathrm{f}$. Dissertation (Professional Master in Public Administration) - Graduate Program of the Professional Master in Public Administration, Federal University of Lavras. Available at: http://repositorio.ufla.br/jspui/handle/1/1013. Accessed on: 02/01/2017. 
DOI: 10.14807/ijmp.v11i4.1109

DI PIETRO, M. S. Z. (2014) Administrative Law. São Paulo: Atlas.

FURTADO, L. R. (2013) Course of administrative law. 4. ed., Rev. current. Belo Horizonte: Forum.

JUSTEN FILHO, M. (2009) Comments on the bidding law and administrative contracts. 13. ed. São Paulo: Dialectic.

LIMA, M. L. (2014) Exploratory study of the difficulties of developing scientific research funded with non-reimbursable funds under the FINEP agreement. $133 \mathrm{f}$. Dissertation (Master) - School of Public and Business Administration, Center for Academic Training and Research, Fundação Getúlio Vargas. Available at: http://bibliotecadigital.fgv.br/dspace/handle/10438/11821. Access on: 03/01/2017.

LUKE, B.; KEARINS, K.; VERREYNNE, M. L. (2011) The risks and returns of new public management: political business. International Journal of Public Sector Management, v. 24, n. 4, p. 325-355. Available at: http://dx.doi.org/10.1108/09513551111133489. Access on: $02 / 01 / 2017$.

MELLO, C. B. (2006) Course of administrative law. São Paulo: Malheiros, 2006.

MENDES, V. L. (2000) Managerial innovation in public administration: a study in the municipal sphere in Brazil. 2000. 325 f. Thesis (Doctorate in Business Administration) Graduate School of Business Administration, School of Business, Federal University of Bahia, Salvador.

MONOBAYEVA, A.; HOWARD, C. (2015) Are Post-Soviet Republics Ready for the New Public Management? The Case of Educational Modernization in Kazakhstan. International Journal of Public Sector Management, v. 28, n. 2. Available at: http://dx.doi.org/10.1108/IJPSM-08- 2014-0102. Accessed on: 02/01/2016.

REZENDE, A. A.; CORRÊA, C. R.; DANIEL, L. P. (2013) The impacts of technological innovation policy on federal universities: an analysis of mining institutions. Journal of Economics and Administration, São Paulo, v. 12, n. 1, p.100-131.

VERMA, D.; SINHA, K. K. (2002) Toward a theory of project interdependencies in high tech R\&D environments. Journal of Operations Management, v. 20, n. 5, p. 451-468.

Available at: http:// www.sciencedirect.com/ science/article/pii/S0272696302000244. Accessed on: 25/10/2017.

YIN, R. K. (2010) Case study: planning and methods. Porto Alegre: Bookman. 